\title{
Parental Knowledge, Attitudes and Practices Towards Paediatric Ear Infections in Riyadh, Saudi Arabia A quantitative study
}

"Muteb M. Alharbi, Mohammed S. Almasri, Abdulrahman Y. Aldayel, Saleh M. Alkhonezan

$$
\begin{aligned}
& \text { معرفة الوالدين والإبجاهات والممارسات بخصوص إلتهابات الأذن لدى الأطفال } \\
& \text { في مدينة الرياض بالمملكة العربية السعودية } \\
& \text { دراسة كمية }
\end{aligned}
$$

متعب موسى الحربي، محمد سعود المصري، عبدالرحمن يوسف الدايل، صالح منصور الخنيزان

ABSTRACT: Objectives: This study aimed to assess the knowledge, attitude and care-seeking practices of parents towards childhood ear infections in Riyadh, Saudi Arabia. Methods: This quantitative cross-sectional study was conducted in Riyadh, Saudi Arabia, between April and June 2018. An online survey was sent to a random selection of parents who were $\geq 18$ years old with children of $\leq 10$ years old. Associations between parental knowledge, attitude, care-seeking practices, socioeconomic status, level of education and age were assessed using the chi square test and logistic regression analysis. Results: A total of 782 subjects participated in this study (response rate: $78.2 \%$ ). Most respondents were knowledgeable (76.2\%), had a positive attitude (78.9\%) and had positive care-seeking practices $(89.5 \%)$. There was a statistically significant difference on both bivariate and multivariate analyses $(P<0.05)$ between parental care seeking practice and knowledge. Parents who sought modern approaches to treatment were found to be almost nine times more likely to have a good attitude towards ear infections than those who did not seek treatment (odds ratio $=8.907,95 \%$ confidence interval $=2.655-34.928 ; P<0.001$ ). A statistically significant relationship was found between good care-seeking practice and age, as well as socioeconomic status ( $P<0.05$ each). Conclusion: This study showed that knowledge, attitude and practice regarding paediatric ear infections were positive in the majority of parents in Riyadh, Saudi Arabia. Future studies should assess other factors that enhance the knowledge, attitude and practices regarding ear infections.

Keywords: Otitis Media; Infection; Knowledge; Attitude; Pediatrics; Parents; Saudi Arabia.

الملخص: الهدف: تهدف هذه الدراسة لقياس المعرفة و الإتجاهـات والممارسات للبحث عن الرعاية الصحية لدى الأطفال الصدال الهصابين بإلتهابات

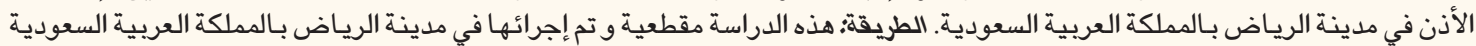

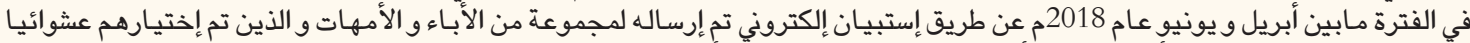

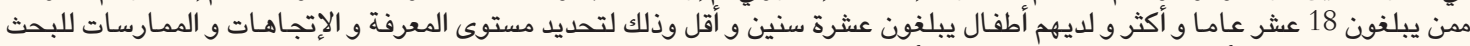

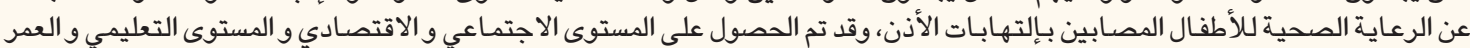

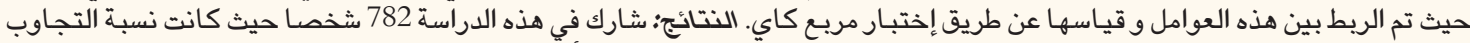

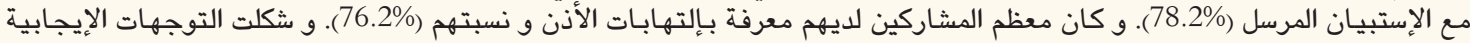

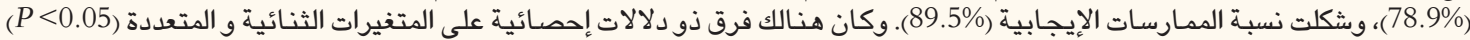

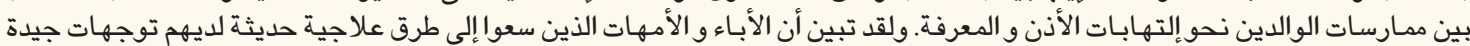

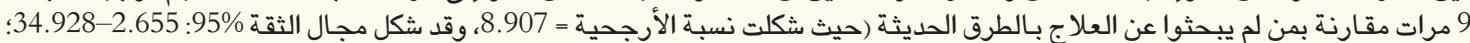

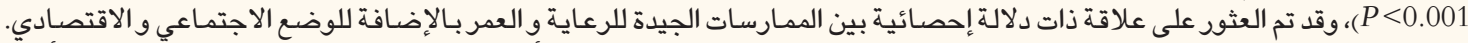

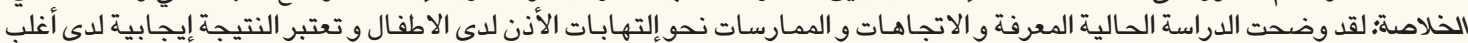

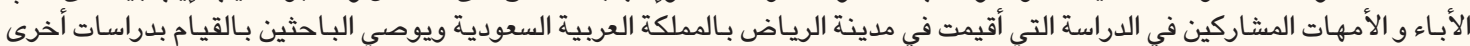

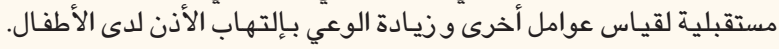

الكلمات المفتاحية: إلتهاب الأذن الوسطى؛ العدوى؛ المعرفة؛ السلوك؛ الأطفال؛ الوالدين؛ السعودية.

\section{ADVANCES IN KNOWLEDGE}

The current study showed that parental knowledge of, attitude towards and care-seeking practice for paediatric ear infections were generally positive in more than two-thirds of the parents living in Riyadh, Saudi Arabia, in 2018.

Higher educational level and socioeconomic status were the main factors responsible for better parental knowledge, attitude and careseeking practice for paediatric ear infections. 


\section{Application to Patient Care}

The results of the study will help the Saudi Arabian Ministry of Health and the Saudi Otolaryngology Society to identify which population groups should be selected for educational programmes.

This study emphasised improvements in parental knowledge, attitude and care-seeking practice to avoid complications of ear infections and reduce the cost of treatment.

$\mathrm{I}$ N DEVELOPING COUNTRIES, EAR DISEASES ARE considered a major public health problem with the potential to affect the psychological and social health of children and their families. ${ }^{1,2}$ Among ear diseases, ear infections are one of the most common infectious diseases in children. ${ }^{2}$ Many studies have shown that the majority of children (approximately $80 \%$ ) will experience at least one episode of otitis media by three years of age and $40 \%$ will have at least six recurrences before the age of seven. ${ }^{3-5}$ Otitis media is defined as the inflammation of the mucosa of the middle ear, including the tympanic cavity, eustachian tube, mastoid antrum and mastoid air cells and can be caused by bacterial or viral infections. ${ }^{6-8}$

Otitis media is subdivided into acute otitis media (AOM), otitis media with effusion (OME), recurrent acute otitis media and chronic suppurative otitis media (CSOM). ${ }^{7}$ AOM presents acutely with both local and systemic signs such as otalgia and fever. ${ }^{9-11}$ In some cases, AOM causes an ear discharge from a perforated tympanic membrane, which may heal spontaneously within 2-14 days. ${ }^{11}$ OME usually occurs after the inflammation of the AOM has resolved. ${ }^{12}$ CSOM involves ongoing inflammation and persistent ear discharge for more than 14 days with perforation of the tympanic membrane. ${ }^{13}$ Children with CSOM may not only present with persistent discharge refractory to medical treatment but may also have hearing loss or tinnitus. ${ }^{5}$ In some cases of CSOM, treatment involves both antibiotic ear drops and surgical repair of the perforated tympanic membrane. ${ }^{14}$ Furthermore, CSOM is associated with serious complications such as mastoiditis, facial nerve paralysis, neck abscess, brain abscess, meningitis, labyrinthitis and lateral sinus thrombosis. ${ }^{5,11,14}$ Globally, an estimated 330 million individuals have had CSOM; 60\% had hearing loss and the majority were children. ${ }^{5,15}$ Hearing loss in children may impede language, cognitive and psychosocial development as well as early communication and school performance. ${ }^{5,14}$ Even in adulthood, hearing loss can be a challenge when seeking employment. ${ }^{5}$ The complications of otitis media result in 28,000 annual deaths globally with meningitis and brain abscesses being the main life-threatening complications. ${ }^{14}$

Otitis media is associated with many risk factors including passive smoking, bottle feeding, short duration of breastfeeding, day-care attendance, low socioeconomic status, upper respiratory tract infections, aller- gies and has a male preponderance. ${ }^{16-19}$ Some of these risk factors are modifiable; ${ }^{20}$ therefore, the prevalence of otitis media can be reduced if parents have the knowledge and willingness to make the appropriate lifestyle alterations. ${ }^{21}$ However, Srikanth et al. found that most parents underestimate the risk of otitis media. ${ }^{21}$ Although otitis media is mostly self-limiting it is the most frequent reason for antibiotic prescriptions for children. ${ }^{7,18}$ Furthermore, most developing countries do not have guidelines for the antibiotic treatment of otitis media and parents/caregivers can obtain antibacterial drugs without prescription. ${ }^{7}$ Consequently, multiple resistance to antibiotics has been increasing. ${ }^{6}$ This study aimed to assess the knowledge, attitude and careseeking practices of parents towards childhood ear infections in Riyadh, Saudi Arabia.

\section{Methods}

This quantitative cross-sectional study was conducted between April and June 2018 in Riyadh, Saudi Arabia. A total of 1,000 Saudi Arabian parents who were $\geq 18$ years old with children $\leq 10$ years old were invited to participate in this online-based study. For the selection process, Riyadh City was divided into five parts: north, east, south, west and central. A nursery school and a primary school were randomly selected from each part. Each selected nursery school and primary school was requested to provide the telephone numbers of parents of children $\leq 10$ years of age (i.e. all nursery school students and primary school students up to and including $4^{\text {th }}$ grade). Participants received an online questionnaire with an explanation of the purpose of the study and an informed consent form prior to the completion of the questionnaire.

The questionnaire was adapted with permission from Mukara et al. and translated to Arabic. ${ }^{5}$ The translation process included cross-cultural validation of the questionnaire and review by a committee of translation at Al Imam Mohammad Ibn Saud Islamic University, Riyadh, Saudi Arabia, in addition to a senior otolaryngologist. Each survey response was linked with an internet protocol address to prevent duplicates.

The self-administrated questionnaire included 12 items that assessed the parental knowledge of, attitude towards and care-seeking practice for paediatric ear 
infections. It comprised of close-ended and multiplechoice questions subdivided into three main sections: seven general knowledge (causes, symptoms, prevention, treatment and consequences of ear infections), two questions on parental attitude towards ear infections and one question each on parental practice for ear infections, health services and the incidence of ear disease in the participant's child. Causes of ear infection include poor hygiene, water in the ears, wax and foreign body and/or microbes. Participants who knew one or more correct cause scored one point (i.e. discharge, hearing loss and pain). Participants who knew two of the three symptoms obtained one point. Participants selected "yes" or "no" for the prevention and treatment questions and obtained one point for each correct answer. Participants who identified one or more correct consequences obtained one point. Participants who scored $>50 \%$ were considered knowledgeable about ear infections. Participants who answered that they would seek care from a medical doctor or nurse for their child's ear infection were considered to have good practice. Reasons for not taking their child to a health centre included "not being worried", "no need for treatment" and being "incurable" were considered a negative attitude. Participants who chose media, health professional, health campaigns or community outreach as information sources were considered to have a positive attitude. Participants who had a total score of $>50 \%$ were considered to have a positive attitude overall.

The questionnaire included demographic variables (age, gender, educational level and socioeconomic status). To ensure reliability and validity, a pilot study was conducted with 10 parents to improve the questionnaire's face/content validity and prevent discrepancies in the parents' responses.

Statistical analysis was performed using RStudio, Version 1.1.149 (RStudio Inc., Boston, Massachusetts, USA). Categorical variables were presented as frequencies and percentages. The chi square test and logistic regression analysis were used to obtain associations between knowledge of the parents, socioeconomic status, level of education, age and care-seeking practices. A $P$ value of $<0.05$ was considered statistically significant.

This study protocol was approved by the Institutional Review Board of Al-Imam Muhammad Ibn Saud Islamic University.

\section{Results}

A total of 839 responses were received, of which 782 were complete and 57 were excluded from the study due to missing data (response rate: 78.2\%). Most participants (61.8\%) were female and ranged from 18-64 years with a mean age of $33.9 \pm 9$ years. The majority of respondents completed a secondary level of education (73.5\%) and reported a middle socioeconomic status (80.9\%) [Table 1].

Most participants reported having information about ear infections (58.6\%), most of which knew that ear infections are treatable (93.7\%) and can be prevented (70.7\%). The majority reported at least one correct symptom (55.9\%) and only 96 (12.3\%) did not know any correct symptoms. The most commonly-listed symptom was pain in the infected ear (79\%), followed by ear discharge from the infected ear (35.7\%). The vast majority of participants reported at least one correct consequence of ear infections (95\%); hearing loss was the most reported consequence (67.6\%) [Table 2].

On bivariate analysis, fathers were found to be significantly less knowledgeable compared to mothers about ear infections (odds ratio $[\mathrm{OR}]=0.4,95 \%$ confidence interval $[\mathrm{CI}]=0.29-0.56 ; P<0.001)$. Parents who completed their secondary education were four times more likely to be knowledgeable about ear infections compared to their uneducated counterparts $(\mathrm{OR}=4.13$, CI: $1.13-15.09 ; P=0.03)$; this finding was still significant after adjustment for other factors $(\mathrm{OR}=5.79, \mathrm{CI}=1.42-23.78 ; P=0.007)$. Vocational education was a significant predictor of good knowledge after adjustment for confounders $(\mathrm{OR}=5.06$,

Table 1: Characteristics of parents $\geq 18$ years old with children of $\leq 10$ years old who participated in this study in Riyadh, Saudi Arabia (N = 782)

$\begin{array}{lc}\text { Characteristics } & \mathbf{n}(\%) \\ \text { Gender } & \\ \text { Female } & 483(61.8) \\ \text { Male } & 299(38.2) \\ \text { Age in years } & \\ \leq 30 & 320(40.9) \\ 31-45 & 386(49.4) \\ 46-60 & 71(9.1) \\ >60 & 5(0.6) \\ \text { Education } & \\ \text { None } & 10(1.3) \\ \text { Primary } & 172(22) \\ \text { Secondary } & 575(73.5) \\ \text { Vocational } & 25(3.2) \\ \text { Socioeconomic status } & \\ \text { Low } & 67(8.6) \\ \text { Middle } & 633(80.9) \\ \text { High } & 82(10.5)\end{array}$


Table 2: Knowledge about ear infections among parents with children $\leq 10$ years old in Riyadh, Saudi Arabia $(N=782)$

\begin{tabular}{|c|c|}
\hline Item & n (\%) \\
\hline \multicolumn{2}{|c|}{ Knowledge of correct symptoms of ear infections* } \\
\hline None & $96(12.3)$ \\
\hline One symptom & $437(55.8)$ \\
\hline Two symptoms & $186(23.8)$ \\
\hline Three symptoms & $63(8.1)$ \\
\hline \multicolumn{2}{|c|}{ Knowledge about prevention of ear infections } \\
\hline Yes & $553(70.7)$ \\
\hline No & $229(29.3)$ \\
\hline \multicolumn{2}{|c|}{ Knowledge about treatment of ear infections } \\
\hline Yes & $733(93.7)$ \\
\hline No & $49(6.3)$ \\
\hline \multicolumn{2}{|c|}{ Knowledge about causes of ear infections } \\
\hline Yes & $642(82.1)$ \\
\hline No & $140(17.9)$ \\
\hline \multicolumn{2}{|c|}{ Knowledge about consequences of ear infections } \\
\hline Yes & $743(95)$ \\
\hline No & $39(5)$ \\
\hline \multicolumn{2}{|c|}{ Consequences of ear infection* } \\
\hline Death & $20(2.6)$ \\
\hline Infection spreads to organs & $215(27.5)$ \\
\hline I don't know & $3(0.4)$ \\
\hline Persistence of disease & $280(35.8)$ \\
\hline Poor school performance & $194(24.8)$ \\
\hline Hearing loss & $529(67.6)$ \\
\hline None & $38(4.9)$ \\
\hline \multicolumn{2}{|c|}{ Overall knowledge ( $\geq 4$ points) } \\
\hline Knowledgeable & $596(76.2)$ \\
\hline Not knowledgeable & $186(23.8)$ \\
\hline
\end{tabular}

"Multiple responses could be chosen.

CI $=0.98-27.48 ; P=0.03)$. Middle and high socioeconomic statuses were significant only before adjustment $(P<0.001$ each). There was a statistically significant correlation between a pluralistic approach to parental ear care-seeking practice and knowledge after the adjustment for potential confounders $(\mathrm{OR}=43.2$, $\mathrm{CI}=6.84-858.21 ; P=0.004)$; this illustrates the benefit of knowledge about ear infections [Table 3].

Overall, most parents (78.9\%) had a positive attitude towards paediatric ear infections [Table 4]. There were no statistically significant correlations between attitude and gender, age, educational level or socioeconomic status. However, care-seeking practice was significantly
Table 3: Knowledge about paediatric ear infections stratified by participant's characteristics $(\mathrm{N}=782)$

\begin{tabular}{|c|c|c|c|c|}
\hline Characteristic & $\begin{array}{c}\text { Unadjusted } \\
\text { OR }(95 \% \mathrm{CI})\end{array}$ & $\begin{array}{c}P \\
\text { value }\end{array}$ & $\begin{array}{l}\text { Adjusted OR } \\
\quad(95 \% \mathrm{CI})\end{array}$ & $\begin{array}{c}P \\
\text { value }^{\dagger}\end{array}$ \\
\hline \multicolumn{5}{|l|}{ Gender } \\
\hline Female & - & - & - & - \\
\hline Male & $\begin{array}{c}0.4 \\
(0.29-0.56)\end{array}$ & $<0.001$ & $\begin{array}{c}0.45 \\
(0.31-0.66)\end{array}$ & $<0.001$ \\
\hline \multicolumn{5}{|l|}{ Age in years } \\
\hline$\leq 30$ & - & - & - & - \\
\hline $31-45$ & $\begin{array}{c}0.78 \\
(0.54-1.10)\end{array}$ & 0.161 & $\begin{array}{c}1.13 \\
(0.77-1.68)\end{array}$ & 0.672 \\
\hline $46-60$ & $\begin{array}{c}1.24 \\
(0.66-2.49)\end{array}$ & 0.507 & $\begin{array}{c}2.23 \\
(1.09-4.93)\end{array}$ & 0.037 \\
\hline$>60$ & $\begin{array}{c}1.12 \\
(0.16-22.09)\end{array}$ & 0.92 & $\begin{array}{c}3.76 \\
(0.37-103.38)\end{array}$ & 0.41 \\
\hline \multicolumn{5}{|l|}{ Education } \\
\hline None & - & - & - & - \\
\hline Primary & $\begin{array}{c}1.77 \\
(0.47-6.61)\end{array}$ & 0.379 & $\begin{array}{c}2.80 \\
(0.68-11.63)\end{array}$ & 0.119 \\
\hline Secondary & $\begin{array}{c}4.13 \\
(1.13-15.09)\end{array}$ & 0.03 & $\begin{array}{c}5.79 \\
(1.42-23.78)\end{array}$ & 0.007 \\
\hline Vocational & $\begin{array}{c}2.57 \\
(0.56-12.23)\end{array}$ & 0.222 & $\begin{array}{c}5.06 \\
(0.98-27.48)\end{array}$ & 0.03 \\
\hline \multicolumn{5}{|c|}{ Socioeconomic status } \\
\hline Low & - & - & - & - \\
\hline Middle & $\begin{array}{c}2.25 \\
(1.32-3.77)\end{array}$ & $<0.001$ & $\begin{array}{c}1.27 \\
(0.69-2.28)\end{array}$ & 0.486 \\
\hline High & $\begin{array}{c}3.58 \\
(1.69-7.91)\end{array}$ & $<0.001$ & $\begin{array}{c}1.8 \\
(0.78-4.28)\end{array}$ & 0.14 \\
\hline \multicolumn{5}{|c|}{ Type of treatment parent would seek } \\
\hline None & - & - & - & - \\
\hline Traditional & $\begin{array}{c}19.25 \\
(3.37-365.1)\end{array}$ & 0.006 & $\begin{array}{c}15.74 \\
(2.60-306.05)\end{array}$ & 0.036 \\
\hline Modern & $\begin{array}{c}38.76 \\
(7.45-711.57)\end{array}$ & 0.005 & $\begin{array}{c}28.85 \\
(5.25-541.24)\end{array}$ & 0.01 \\
\hline Pluralism & $\begin{array}{c}53.9 \\
(9.02-1,044.14)\end{array}$ & $<0.001$ & $\begin{array}{c}43.2 \\
(6.84-858.21)\end{array}$ & 0.004 \\
\hline
\end{tabular}

$O R=$ odds ratio; $C I=$ confidence interval

*Using bivariate analysis. ${ }^{\dagger}$ Using multivariate analysis.

associated with attitude on a bivariate analysis. The odds of having good attitude towards ear infections among parents who sought modern approaches was eight times higher than in parents who did not seek medical care $(\mathrm{OR}=8.25, \mathrm{CI}=2.55-31.30 ; P<0.001)$. This relation remained significant even after the adjustment of other factors $(\mathrm{OR}=8.97, \mathrm{CI}=2.65-34.92$; $P<0.001)$. Similarly, the odds were also higher in parents who practice pluralism compared to parents who do not seek medical care $(\mathrm{OR}=11.11, \mathrm{CI}=2.89-49.64$; $P<0.001)$; this finding remained significant on multivariate analysis $(\mathrm{OR}=12.73, \mathrm{CI}=3.201-58.79 ; P<0.001)$ [Table 5]. 
Table 4: Attitudes towards and care-seeking practices for paediatric ear infections among parents with children $\leq 10$ years old in Riyadh, Saudi Arabia $(\mathrm{N}=782)$

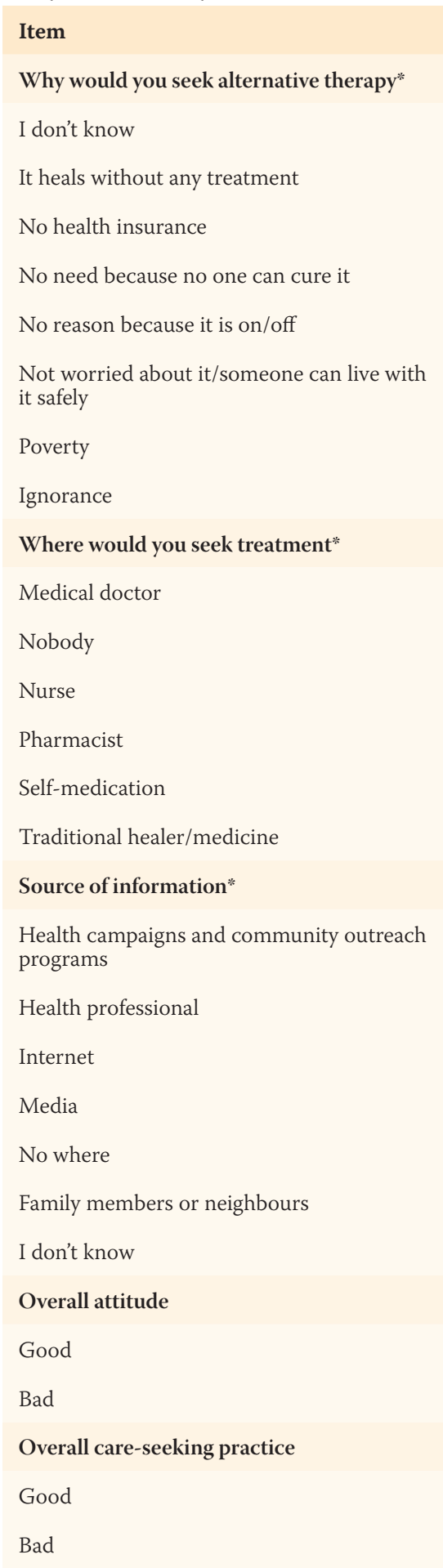

$690(88.2)$

$60(7.7)$

$13(1.7)$

$164(21)$

$452(57.8)$

464. (59.3)

$137(17.5)$

$160(20.5)$

$617(78.9)$

$165(21.1)$

$700(89.5)$

$82(10.5)$
Table 5: Attitude towards paediatric ear infections stratified by participant's characteristics $(\mathrm{N}=782)$

$\begin{array}{lcccc}\text { Characteristic } & \begin{array}{c}\text { Unadjusted } \\ \text { OR (95\% CI) }\end{array} & \begin{array}{c}\boldsymbol{P} \\ \text { value }^{*}\end{array} & \begin{array}{c}\text { Adjusted OR } \\ (\mathbf{9 5 \%} \text { CI) }\end{array} & \begin{array}{c}\boldsymbol{P} \\ \text { value }^{+}\end{array} \\ \begin{array}{l}\text { Gender } \\ \text { Female }\end{array} & - & - & - & - \\ \text { Male } & 0.94 & 0.73 & 1.04 & 0.812 \\ & (0.66-1.34) & & (0.71-1.55) & \\ \text { Age in years } & & & & \\ \leq 30 & - & - & - & - \\ 31-45 & 1.12 & 0.512 & 1.28 & 0.21 \\ & (0.78-1.61) & & (0.86-1.89) & \\ 46-60 & 1.29 & 0.44 & 1.72 & 0.132 \\ & (0.69-2.58) & & (0.87-3.63) & \\ >60 & 1.16 & 0.894 & 2.15 & 0.527 \\ & (0.16-22.9) & & (0.26-47.18) & \end{array}$

Education

None

*Multiple responses could be chosen.

The majority of parents had positive care-seeking practices $(89.5 \%)$ and most preferred to seek treatment from a medical doctor (88.2\%). Very few parents stated that they would seek help from a traditional healer (1.7\%) or not seek help at all (1.2\%). The main reason for seeking alternative therapy was ignorance (48.5\%) followed by poverty (35.7\%) [Table 4].
Primary

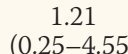

0.789

1.48 $(0.29-5.89)$

0.593

Secondary

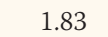

1.83
$(0.39-6.7)$

0.386

2.24

(0.45-8.8)

Vocational

$$
0.91
$$$$
\text { (0.16-4.3) }
$$

0.908

1.16

$(0.2-5.82)$

0.268

0.854

Socioeconomic status

Low

Middle

$$
\begin{gathered}
1.36 \\
(0.75-2.38)
\end{gathered}
$$

0.284

0.92

(0.47-1.7)

High

$$
\begin{gathered}
1.95 \\
(0.88-4.42)
\end{gathered}
$$

0.103

1.18

(0.49-2.85)

0.799

0.699

Type of treatment parent would seek

None

Traditional

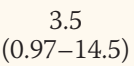

0.063

3.83

(1.03-16.31)

Modern

$$
8.25
$$$$
\text { (2.55-31.3) }
$$

Pluralism

$$
\begin{gathered}
11.11 \\
2.89-49.64
\end{gathered}
$$$$
<0.001
$$$$
8.9
$$$$
\text { (2.65-34.92) }
$$$$
12.73
$$$$
(3.2-58.79)
$$

$O R=$ odds ratio $; C I=$ confidence interval .

"Using bivariate analysis. ${ }^{+}$Using multivariate analysis.

There was a significant association between age and care-seeking practice before and after the adjustment of potential confounders. Parents $>45$ years were more likely to have better care-seeking practice than parents $<31$ years $(P<0.05)$. The odds of good careseeking practices were higher in parents who had a secondary level education compared to parents who had no education $(\mathrm{OR}=5.17, \mathrm{CI}=1.08-19.32 ; P=0.02)$. Parents with middle $(\mathrm{OR}=4.47, \mathrm{CI}=2.43-8.00 ; P<0.001)$ and high $(\mathrm{OR}=4.55, \mathrm{CI}=1.86-12.38 ; P<0.001)$ socioeconomic status were four times more likely to have positive practice regarding ear infections than parents with low socioeconomic status; this finding was also 
Table 6: Care-seeking practices for paediatric ear infections stratified by participant's characteristics $(\mathrm{N}=782)$

\begin{tabular}{|c|c|c|c|c|}
\hline Characteristic & $\begin{array}{l}\text { Unadjusted } \\
\text { OR (95\% CI) }\end{array}$ & $\begin{array}{c}P \\
\text { value }^{*}\end{array}$ & $\begin{array}{c}\text { Adjusted } \\
\text { OR }(95 \% \mathrm{CI})\end{array}$ & $\begin{array}{c}P \\
\text { value }^{\dagger}\end{array}$ \\
\hline \multicolumn{5}{|l|}{ Gender } \\
\hline Female & - & - & - & - \\
\hline Male & $\begin{array}{c}0.52 \\
(0.32-0.82)\end{array}$ & 0.006 & $\begin{array}{c}0.76 \\
(0.45-1.27)\end{array}$ & 0.294 \\
\hline \multicolumn{5}{|l|}{ Age in years } \\
\hline$\leq 30$ & - & - & - & - \\
\hline $31-45$ & $\begin{array}{c}0.63 \\
(0.36-1.07)\end{array}$ & 0.09 & $\begin{array}{c}0.7 \\
(0.39-1.24)\end{array}$ & 0.235 \\
\hline $46-60$ & $\begin{array}{c}0.31 \\
(0.15-0.66)\end{array}$ & 0.002 & $\begin{array}{c}0.37 \\
(0.16-0.83)\end{array}$ & 0.014 \\
\hline$>60$ & $\begin{array}{c}0.05 \\
(0.007-0.32)\end{array}$ & 0.002 & $\begin{array}{c}0.1 \\
(0.01-0.76)\end{array}$ & 0.025 \\
\hline \multicolumn{5}{|l|}{ Education } \\
\hline None & - & - & - & - \\
\hline Primary & $\begin{array}{c}2.4 \\
(0.49-9.28)\end{array}$ & 0.224 & $\begin{array}{c}1.57 \\
(0.25-7.29)\end{array}$ & 0.585 \\
\hline Secondary & $\begin{array}{c}5.17 \\
(1.08-19.32)\end{array}$ & 0.02 & $\begin{array}{c}2.37 \\
(0.38-10.72)\end{array}$ & 0.296 \\
\hline Vocational & $\begin{array}{c}0.76 \\
(0.13-3.53)\end{array}$ & 0.736 & $\begin{array}{c}0.56 \\
(0.08-3.12)\end{array}$ & 0.527 \\
\hline \multicolumn{5}{|c|}{ Socioeconomic status } \\
\hline Low & - & - & - & - \\
\hline Middle & $\begin{array}{c}4.47 \\
(2.43-8)\end{array}$ & $<0.001$ & $\begin{array}{c}3.44 \\
(1.76-6.59)\end{array}$ & $<0.001$ \\
\hline High & $\begin{array}{c}4.55 \\
(1.86-12.38)\end{array}$ & $<0.001$ & $\begin{array}{c}4.23 \\
(1.56-12.69)\end{array}$ & 0.006 \\
\hline
\end{tabular}

$O R=$ odds ratio; $C I=$ confidence interval.

*Using bivariate analysis. ${ }^{\dagger}$ Using multivariate analysis.

significant after adjustment for potential confounders $(\mathrm{OR}=3.44, \mathrm{CI}=1.76-6.59 ; P<0.001$ and $\mathrm{OR}=4.23$, $\mathrm{CI}=1.56-12.69 ; P=0.006)$ [Table 6].

\section{Discussion}

This study measured the knowledge of, attitude towards and care-seeking practices for paediatric ear infections among parents with children $\leq 10$ years of age. The majority of participants (76.6\%) were knowledgeable about ear infections, while $78.9 \%$ had good attitude and $89.5 \%$ reported positive care-seeking practices. These results support the findings from other similarly conducted studies. .,21,22 $^{2}$

There was a significant positive correlation between female gender and knowledge, attitude and practice. Di Berardino et al. also found that females had better knowledge than their male counterparts about ear and hearing management. ${ }^{23}$
The majority of participants (49.4\%) were aged between 31-45 years; however, this age group did not significantly correlate with knowledge of or attitude towards ear infections. Parents $>60$ years old were most likely to have good care-seeking practices. Irwan et al. studied health seeking behaviours among elderly people in an Indonesian community and found that younger individuals are less likely to seek healthcare, based on monthly health check-ups as a tool of assessment. $^{24}$

Those who practiced less modern medicine attributed their reluctance to seek care to poverty (35.7\%), lack of a health insurance (24.8\%) and ignorance (48.5\%). These proportions align with studies on knowledge, attitudes and practices in regard to otitis media in different parts of the world and highlights that CSOM is a disease of the low-income population.,21,25 In addition, poverty was associated with the inability to pay for healthcare services as well as the transport costs even if the child had medical insurance. Parents with higher levels of education were more likely to have more knowledge and positive care-seeking practices compared to parents with lower levels of education. However, there was no significant relationship between attitude and education level. Yip et al. found an association between education status and healthcare seeking behaviour. ${ }^{26}$

Overall, the current study found lower levels of knowledge about symptoms compared to previous studies; only $23 \%$ of the participants could identify two symptoms of ear infections, while almost half could in Mukara et al's study. ${ }^{5}$ The fluctuating attitude and healthcare seeking behaviour of medical treatment revealed in the current study may be due to a shortage of knowledge, the presence of poverty and/or dissatisfaction with the provided healthcare services such as referral delays. These findings are in agreement with Shaheen et al's study. ${ }^{27}$ In Bangladesh, Shaheen et al. found that the majority (85\%) of CSOM patients preferred to seek over-the-counter medications instead of aid from medical staff. ${ }^{27}$ Therefore, to increase the usage of healthcare services, it is important to promote awareness of prevention and treatment. Social status can have an important role in healthcare-seeking practices and involves provision, planning and improvement of healthcare services.

To the best of the authors' knowledge, this is the first study to investigate knowledge of, attitude towards and care-seeking practice for ear infections among parents of children $\leq 10$ years of age in Saudi Arabia. The sample can be considered representative of Riyadh as data were collected from five different parts of Riyadh 
City. Thus, the current study represents a starting point for further investigations about ear infections in the Saudi Arabian population.

However, this study did have limitations. The information was collected through a self-reporting questionnaire and is therefore inherently subject to misclassification. Moreover, one questionnaire cannot encompass all aspects of ear infections. Future studies should assess more extensive factors that could influence parental practices regarding paediatric ear infections. The findings of this study cannot be generalised on a national level due to the cultural variation among different populations living in different regions of Saudi Arabia.

\section{Conclusion}

Most Saudi Arabian parents in this study had good behaviour in terms of knowledge of, attitude towards and care-seeking practice for paediatric ear infections. The main factors associated with these positive behaviours were the educational level and socioeconomic status of the parents. These findings suggest that it may be beneficial to conduct educational programmes regarding paediatric ear infections for Saudi parents to direct them towards better behaviours.

\section{CONFLICT OF INTEREST}

The authors declare no conflicts of interest.

\section{FUNDING}

No funding was received for this study.

\section{References}

1. Biswas AC, Joarder AH, Siddiquee BH. Prevalence of CSOM among rural school going children. Mymensingh Med J 2005; $14: 152-5$.

2. Kohli C, Kadirvelu U, Garg S, Sharma N. Burden of ear morbidities among children in primary care setting in Delhi. Clin Epidemiol Glob Health 2016; 4:S12-16. https://doi.org/10.1 016/j.cegh.2016.08.010.

3. Vergison A, Dagan R, Arguedas A, Bonhoeffer J, Cohen R, Dhooge I, et al. Otitis media and its consequences: Beyond the earache. Lancet Infect Dis 2010; 10:195-203. https://doi.org/10.1016/S1473-3 099(10)70012-8.

4. Teele DW, Klein JO, Rosner B. Epidemiology of otitis media during the first seven years of life in children in greater Boston: A prospective, cohort study. J Infect Dis 1989; 160:83-94. https://doi.org/10.1093/infdis/160.1.83.

5. Mukara KB, Waiswa P, Lilford R, Tucci DL. Knowledge and care seeking practices for ear infections among parents of under five children in Kigali, Rwanda: A cross-sectional study. BMC Ear Nose Throat Disord 2017; 17:7. https://doi.org/10.1186/s12901017-0040-1.
6. Ilechukwu GC, Ilechukwu CGA, Ubesie AC, Ojinnaka CN, Emechebe GO, Iloh KK. Otitis media in children: Review article. Open J Pediatr 2014; 4:47-53. https://doi.org/10.4236/ ojped.2014.41006.

7. DeAntonio R, Yarzabal JP, Cruz JP, Schmidt JE, Kleijnen J. Epidemiology of otitis media in children from developing countries: A systematic review. Int J Pediatr Otorhinolaryngol 2016; 85:65-74. https://doi.org/10.1016/j.ijporl.2016.03.032.

8. Massa HM, Cripps AW, Lehmann D. Otitis media: Viruses, bacteria, biofilms and vaccines. Med J Aust 2009; 191:S44-9. https://doi.org/10.5694/j.1326-5377.2009.tb02926.x.

9. European Medicines Agency and Heads of Medicines Agencies. Guideline on good pharmacovigilance practices (GVP): Module $\mathrm{V}$ - Risk management systems (Rev 2). Amsterdam, Netherlands: European Medicines Agency. EMA/838713/2011 Rev 2.

10. Atkinson H, Wallis S, Coatesworth AP. Acute otitis media. Postgrad Med 2015; 127:386-90. https://doi.org/10.1080/0032 5481.2015.1028872.

11. Qureishi A, Lee Y, Belfield K, Birchall JP, Daniel M. Update on otitis media - prevention and treatment. Infect Drug Resist 2014; 7:15-24. https://doi.org/10.2147/IDR.S39637.

12. Atkinson $\mathrm{H}$, Wallis $\mathrm{S}$, Coatesworth AP. Otitis media with effusion. Postgrad Med 2015; 4:381-5. https://doi.org/10.1080/ 00325481.2015 .1028317$.

13. Wallis S, Atkinson H, Coatesworth AP. Chronic otitis media. Postgrad Med 2015; 127:391-5. https://doi.org/10.1080/00325 481.2015.1027133.

14. World Health Organization. Chronic suppurative otitis media: Burden of illness and management options. Geneva, Switzerland: World Health Organization. ISBN 9241591587. P. 11,12,22,47-70.

15. Monasta L, Ronfani L, Marchetti F, Montico M, Vecchi Brumatti L, Bavcar A, et al. Burden of disease caused by otitis media: Systematic review and global estimates. PLoS One 2012; 7:e36226. https://doi.org/10.1371/journal.pone.0036226.

16. Gultekin E, Develioğlu ON, Yener M, Ozdemir I, Külekçi M. Prevalence and risk factors for persistent otitis media with effusion in primary school children in Istanbul, Turkey. Auris Nasus Larynx 2010; 37:145-9. https://doi.org/10.1016/j.anl.20 09.05.002.

17. Kırıs M, Muderris T, Kara T, Bercin S, Cankaya H, Sevil E. Prevalence and risk factors of otitis media with effusion in school children in Eastern Anatolia. Int J Pediatr Otorhinolaryngol 2012; 76:1030-5. https://doi.org/10.1016/j.ijporl.2012.03.027.

18. Humaid AH, Ashraf AH, Masood KA, Nuha AH, Saleh AD, Awadh AM. Prevalence and risk factors of otitis media with effusion in school children in Qassim Region of Saudi Arabia. Int J Health Sci (Qassim) 2014; 8:325-34. https://doi.org/10.12 $816 / 0023990$.

19. Adeyemo AA. Knowledge of caregivers on the risk factors of otitis media. Indian J Otol 2012; 18:184-8. https://doi.org/10.41 03/0971-7749.104795.

20. Kerschner JE, Lindstrom DR, Pomeranz A, Rohloff R. Comparison of caregiver otitis media risk factor knowledge in suburban and urban primary care environments. Int J Pediatr Otorhinolaryngol 2005; 69:49-56. https://doi.org/10.1016/j.ijporl.200 4.08.004.

21. Srikanth S, Isaac R, Rebekah G, Rupa V. Knowledge, attitudes and practices with respect to risk factors for otitis media in a rural South Indian community. Int J Pediatr Otorhinolaryngol 2009; 73:1394-8. https://doi.org/10.1016/j.ijporl.2009.06.024.

22. Barber C, Ille S, Vergison A, Coates H. Acute otitis media in young children - what do parents say? Int J Pediatr Otorhinolaryngol 2014; 78:300-6. https://doi.org/10.1016/j.ijporl.201 3.11.030. 
23. Di Berardino F, Forti S, Iacona E, Orlandi GP, Ambrosetti U, Cesarani A. Public awareness of ear and hearing management as measured using a specific questionnaire. Eur Arch Otorhinolaryngol 2013; 270:449-53. https://doi.org/10.1007/s00405012-1961-3.

24. Irwan AM, Kato M, Kitaoka K, Kido T, Taniguchi Y, Shogenji M. Self-care practices and health-seeking behavior among older persons in a developing country: Theories-based research. Int J Nurs Sci 2016; 3:11-23. https://doi.org/10.1016/j.jinss.2016.02.010.

25. Clarke S, Richmond R, Worth H, Wagle RR. A study protocol for a cluster randomised trial for the prevention of chronic suppurative otitis media in children in Jumla, Nepal. BMC Ear Nose Throat Disord 2015; 15:4. https://doi.org/10.1186/s12901-0150017-x.
26. Yip WC, Wang H, Liu Y. Determinants of patient choice of medical provider: A case study in rural China. Health Policy Plan 1998; 13:311-22. https://doi.org/10.1093/heapol/13.3.311.

27. Shaheen MM, Raquib A, Ahmad SM. Chronic suppurative otitis media and its association with socio-econonic factors among rural primary school children of Bangladesh. Indian J Otolaryngol Head Neck Surg 2012; 64:36-41. https://doi.org/10.1007/s120 70-011-0150-9. 